\title{
PERFORMANCE EVALUATION OF SELECT PAINT COMPANIES IN INDIA
}

\author{
Dr. P. Rajender \\ Assistant Professor \& Head of the Department of Commerce \& Business Management, \\ Chaitanya Institute of Science \& Technology (Deemed to be University), Warangal, India
}

\begin{abstract}
Profit maximization is the basic objective of every firm. In the present competitive world no firm can sustain without profit. Generally profit means income over expenditure of a firm. To evaluate the financial performance of firm, it is important to analyzing the profitability position of firm over a period of time. In financial accounting there are several techniques and tools are available for measuring Performance of an organization. The present study attempts to analyze the financial performance of the select paint companies in India using Ratio analysis as well as Statistical techniques have used to interpret the data. The study period is of 5 years from 2014-15 to 2018-19.The study concluded that Profitability position of the select Paint companies seems to be good and satisfactory.
\end{abstract}

Keywords: Ratio analysis, Profitability, Statistical tools.

Cite this Article: Dr. P. Rajender, Performance Evaluation of Select Paint Companies in India, International Journal of Management (IJM), 11 (1), 2020, pp. 56-60.

$\mathrm{http} / / /$ iaeme.com/Home/issue/IJM?Volume=11\&Issue=1

\section{INTRODUCTION}

In general every firm requires profit for its existence, Expansion and modification. To measure the overall efficiency of a business Profits are the useful measures. Profitability can be defined as financial measure of financial success achieved by an organization. Profit analysis is very important for internal stake holders as well as external stake holders. Internal stake holders like shareholders, employees who are expected to get revenue in the form of dividends, bonus and hike in salaries etc. The external stake holders (Bankers, government, Creditors) are those who are sources of funds for the firm, and they are interested in profits of an organization because for the interest coverage and debt coverage.

The Indian paint industry is segmented into decorative and industrial market. Paint industry is growing very fast in India, due to rapid industrialization and increasing urbanization. The manufacture of paint by Indian paint industry is at Rs.49, 800 Crore in 2016-17.Indian paint industry estimated to reach 70,000 Crore by 2021-22. The share of decorative paint is $75 \%$ and share of industrial paint is $25 \%$. India has one of the lowest per capita paint consumption at $1 \mathrm{~kg} /$ per annum as against $20 \mathrm{~kg} / \mathrm{per}$ annum of the developed countries. The Indian paint market is expected to reach INR 708 billion by financial year 
2019-20 from approximately INR 400 billion a couple of years back. The decorative paint market is expected to witness CAGR of $12.7 \%$ and industrial paint market CAGR of $9.5 \%$.

REVIEW OF LITERATURE:

Ashok kumar (2013) studied liquidity position of five leading companies and it has been found that liquidity position of small companies is better as compare to big ones.

\section{OBJECTIVE OF THE STUDY}

To analyze the profitability position of select paint companies in India.

\section{RESEARCH METHODOLOGY}

The study is based on secondary data and such data have been collected from annual reports of the respective companies, magazines, journals, financial data web site and other published information.

The sample for the study is study top 3 companies have been selected based on their market capitalization. The selected three companies are.

1. Asian paints

2. Nerolac paints

3. Berger paints.

The study covers the period of 5 years i.e. from 2014-15 to 2018-19.

To analyze the data and to draw conclusions various financial tools are use like-Operating profit ratio, gross profit ratio, net profit ratio, Return on assets ratio, return on equity ratio. Further a comprehensive analysis is carried by applying statistical tools such as mean, standard deviation and coefficient of variation.

The Present study analyzes the profit position of the selected paint companies using the following profitability measures.

1. Operating profit ratio $=$ operating profit $/$ net sales

2. Gross profit ratio $=$ gross profit $/$ net sales

3. Net profit ratio $=$ Net profit/net sales

4. Return on assets ratio $=$ net profit/total assets

5 . Return on equity $=\mathrm{Net}$ profit/equity shareholder's fund

NOTE: To convert the above ratios into \%, multiply with 100 .

\section{ANALYSIS AND DISCUSSION}

Table 1 Operating Profit Ratio

\begin{tabular}{|c|c|c|c|}
\hline Year & Asian paints & Nerolac paints & Berger paints \\
\hline $2014-15$ & 17.25 & 12.47 & 12.48 \\
\hline $2015-16$ & 19.06 & 14.94 & 14.69 \\
\hline $2016-17$ & 21.11 & 18.27 & 15.67 \\
\hline $2017-18$ & 20.61 & 17.29 & 15.73 \\
\hline $2018-19$ & 20.18 & 14.34 & 14.68 \\
\hline Mean & 19.64 & 15.46 & 14.65 \\
\hline Standard deviation & 1.53 & 2.33 & 1.31 \\
\hline C.V & 7.78 & 15.07 & 8.94 \\
\hline
\end{tabular}

Source: computed from complied data 
From the above table it is clear that the operating profit ratio of Asian paints is fluctuating from year to year. It is recorded the highest (21.11) in the year 2016-17. On the other hand Nerolac paints recorded the highest operating profit ratio is 18.27 in the year 2016-17. Where as the operating profit ratio of Berger paints is fluctuating year to year and it is recorded the highest (15.73) in the year 2017-18.

The mean value of Asian paints shows highest 19.64 followed by Nerolac and Berger.

Coefficient of variation(C.V) of Asian paints 7.79, Nerolac paints 15.07, Berger paints 8.94, Which indicates that Nerolac paints shows higher risk and lower return compare to Berger paints and Asian paints.

Therefore, External stakeholder like- Creditors and bankers don't want to take high risk by providing loans to the Nerolac Paints. Coefficient of Variation for Asian paint is 7.79 which is minimum as compare to Nerolac paints and Berger paints. Hence, Asian paints shows low risk and higher returns. Therefore, Share holders are very much interested to buy the company shares.

Table 2 Gross Profit Ratio

\begin{tabular}{|c|c|c|c|}
\hline Year & Asia paints & Nerolac paints & Berger paints \\
\hline $2014-15$ & 16.12 & 14.28 & 11.83 \\
\hline $2015-16$ & 20.89 & 14.58 & 14.11 \\
\hline $2016-17$ & 17.04 & 17.41 & 12.82 \\
\hline $2017-18$ & 21.70 & 14.72 & 13.88 \\
\hline $2018-19$ & 18.72 & 10.51 & 11.63 \\
\hline Mean & 18.89 & 14.3 & 12.85 \\
\hline Standard deviation & 2.39 & 2.46 & 1.14 \\
\hline C.V & 12.65 & 17.2 & 8.87 \\
\hline
\end{tabular}

Source: computed from annual reports.

From the table 2 it is clear that gross profit ratio of the selected paint companies is fluctuating year to year. In the year 2017-18 Asian paints recorded highest gross profit ratio (21.70) compare to other companies.

The mean value of Asian paints shows highest 18.89 followed by Nerolac paints, and Berger Paints Which is the lowest 12.85.

Coefficient of variation of Nerolac Paints (17.2) is higher than other two companies. Hence Nerolac Paints Company is less consistency.

Table 3 NET Profit Ratio

\begin{tabular}{|c|c|c|c|}
\hline Year & Asian paints & Nerolac paints & Berger paints \\
\hline $2014-15$ & 11.39 & 7.65 & 6.98 \\
\hline $2015-16$ & 12.63 & 23.26 & 8.58 \\
\hline $2016-17$ & 14.24 & 12.65 & 10.51 \\
\hline $2017-18$ & 13.37 & 11.25 & 9.14 \\
\hline $2018-19$ & 13.02 & 9.03 & 7.95 \\
\hline Mean & 12.93 & 12.77 & 8.63 \\
\hline Standard deviation & 1.04 & 4.19 & 1.32 \\
\hline C.V & 8.04 & 32.8 & 15.29 \\
\hline
\end{tabular}

Source: Computed from Annual reports

From the above table 3, it is clear that Net profit ratio is changing year to year for all the companies. Nerolac paints recorded highest net profit ratio (23.26) in the year 2015-16, where 
as Berger paints recorded lowest net profit ratio(6.98) in the year 2014-15. The mean value of Asian paints 12.93 which is highest followed by Nerolac paints company.

The coefficient of variation of Asian paints (8.04), Nerolac paints (32.8) and Berger Paints Company (15.29). The company which has lower coefficient of variation is said to be more consistent.

Table 4 Return on Assets Ratio

\begin{tabular}{|c|c|c|c|}
\hline Year & Asian paints & Nerolac paints & Berger paints \\
\hline $2014-15$ & 18.25 & 16.58 & 16.82 \\
\hline $2015-16$ & 19.09 & 39.15 & 22.49 \\
\hline $2016-17$ & 17.39 & 17.91 & 21.84 \\
\hline $2017-18$ & 16.35 & 16.47 & 18.88 \\
\hline $2018-19$ & 16.23 & 13.63 & 16.96 \\
\hline Mean & 19.64 & 20.75 & 19.38 \\
\hline Standard deviation & 1.56 & 10.40 & 2.66 \\
\hline C.V & 7.9 & 50.12 & 13.72 \\
\hline
\end{tabular}

Source: Computed from complied data

From the above table, it shows that return on assets fluctuating year to year. Nerolac paints recorded highest (39.15) it indicates that firm is utilizing its assets effectively to generate profits. Mean value of Nerolac paints shows highest (20.75) followed by Asian Paints.

Coefficient of variation of return on assets of Asian paints is lower than the Nerolac Paints which indicates that Asian Paints is more consistency.

Table 5 Return on Equity

\begin{tabular}{|c|c|c|c|}
\hline Year & Asian paint & Nerolac paints & Berger Paints \\
\hline $2014-15$ & 31.37 & 17.01 & 20.57 \\
\hline $2015-16$ & 32.18 & 38.92 & 23.49 \\
\hline $2016-17$ & 25.39 & 17.91 & 23.21 \\
\hline $2017-18$ & 24.29 & 16.52 & 20.14 \\
\hline $2018-19$ & 24.01 & 13.64 & 18.50 \\
\hline Mean & 27.45 & 20.8 & 21.18 \\
\hline Standard deviation & 3.99 & 10.25 & 2.13 \\
\hline C.V. & 14.5 & 49.3 & 10.05 \\
\hline
\end{tabular}

Source: Computed from complied data

From the above table, it is clear that Nerolac paints shows highest (38.92) in the year 2015-16. The mean value of Asian paints shows highest (27.45) followed by Berger paints and Nerolac paints shows lowest (20.8) mean value.

Coefficient of variation of Nerolac Paints company is higher than the Asian paints which indicates that Nerolac Paints is less consistency.

\section{CON CLUSION}

The study attempts to analyze the Profitability of selected Paint companies in India in terms of Operating profit ratio, gross profit ratio, Net profit ratio, return on assets ratio and return on equity ratio. It can be concluded that Nerolac Paints is utilizing its assets more effectively. In terms of Return on equity ratio Berger Paints is more consistency. However, Asian paints mean value is higher than Nerolac paints in terms of Net profit ratio it means that Asian paints company generated more profits. On over all the profitability position of all the select paint companies good and satisfactory for the study period. 
Performance Evaluation of Select Paint Companies in India

\section{REFERENCES}

[1] Annual reports of Asian Paint Company.

[2] Annual reports of Nerolac paint company.

[3] Annual reports of Berger Paints Company.

[4] Research journal like International journal of research in commerce and management.

[5] M.Y. khan and P.K. Jain financial management

[6] Shashi K gupta Financial Management Kalyani publishers.

[7] Moneycontrol.com 